\title{
СОЦІОЛОГІЯ РЕЛІГї
}

\author{
О.Дурманенко“" (м. Київ)
}

\section{ОНТОЛОГІЧНА БЕЗПЕКА ОСОБИСТОСТІ ЯК ПРЕДМЕТ СОЦІОЛОГІї РЕЛІГІї}

Сучасні соціогуманітарні науки, зазнаючи впливу трансформаційних процесів, переосмислючи усталені поняття, звертаються до проблем, які раніше начебто перебували в „затінку” актуального. Одним з таких об'єктів дослідження є онтологічна безпека особистості, вивченням якої займаються різні науки. Питання безпеки особистості не може оминути і соціологія релігії, оскільки релігія, як соціально-духовний феномен, безпосередньо вплетена в механізми формування означеного стану особистості.

Однією 3 найвиразніших ознак сучасних цивілізаційних процесів $є$ зростання свободи особи. Однак досягнення людиною такого стану носить суперечливий характер: зростання свободи нерозривно пов'язане 3 тими явищами, які постійно намагаються обмежити цю сутнісну силу людини. Адже і в сучасному світі різні інституції або ж утворення соціального світу прагнуть втрутитися у внутрішній світ особистості, іiі приватне життя. Таке втручання суб'єктивно розглядається як ворожий акт, що своєю чергою здатне призвести до сприйняття соціального світу як небезпечного, ризикованого для життя. Особливо це характерно для суспільств, що зазнають соціальних змін, у стані яких перебуває і сучасна Україна. Джерел, які допомагають індивіду об' єктивно сприймати буття, таким чином наповнюючи його почуттям захищеності, небагато. Одним 3 них $\epsilon$ онтологічна безпека особистості. Однак через свою суб'єктивність вона вимагає певного зовнішнього еквіваленту та чинника. Ним, на нашу думку, може виступати релігія, що в силу свого впливу не лише примирює індивіда 3 буттям, а й трансформує його.

Останні дослідження засвідчують, що в історії соціологічної думки існували визначення релігії, які безпосередньо торкалися безпечного стану людини. Так, з творчості В. Липинського випливає, що релігія є містичним станом буття людини, коли вона відчуває зв'язок з Вищими Силами, які забезпечують їй досягнення життєвої мети, дає людині заохочення, творить віру в щасливе розв'язання життєвих негараздів [Цит. за: Кондратик Л.Й.

" Дурманенко О.О. - аспірант кафедри соціології Інституту соціальних наук Волинського національного університету імені Лесі У країнки. 
У країнське релігієзнавство доби національного відродження. -Луцьк, 2004. С.51]. Подібні ідеї знаходимо в класиків соціології релігії Е.Дюркгейма, Ж.Марітена, Е.Жильсона та ін. 3 іншого боку, наявні такі підходи до релігії, коли остання розглядається, власне, як еквівалент онтологічної безпеки. Наприклад, Г. Зіммель, дошукуючись суті, приходить до висновку стосовно прямого впливу релігії на людину або ж спільноту як невід'ємний елемент буття, що формує спільний соціальний простір, а також забезпечує цілісність життя та безпечне його сприйняття [ Зиммель Г. Релігія. Соціальнопсихологический этюд// Зиммель Г.Избраное в двух томах. - Т.1. -М., 1996. C. 546-547].

Таким чином, вивчення онтологічної безпеки особистості з боку соціології релігії як наукової дисципліни, що займається дослідженнями феномену релігії на стику з психологією та історією релігії, допоможе, на нашу думку, означивши вітальність даного почуття, сформувати його образ як певного соціального еквіваленту релігії. Говорячи про еквівалентність, ми, насамперед, маємо на увазі структурно-функціональну складову останнього [ Веремчук В.И. Социология религии. - М., 2004. - С.11].

В галузі соціології релігії наукові розвідки, що безпосередньо торкаються онтологічної безпеки особистості, майже відсутні. В той же час наявні роботи в інших галузях науки, автори яких побічно торкаються означеної проблеми. Передусім, це роботи сучасних авторів, які присвячені функційності релігії і щонайперше т.з. ії опійній функції, яка забезпечує примирення індивіда з викликами зовнішнього середовища. Насамперед, тут слід відзначити доробок І.А. Клімова, С.Л. Рубінштейна, А.В. Брушлинського, Л. Виговського, М.Хейдметса та ін.

Метою даної статті $€$ аналіз релігії як важливого чинника онтологічної безпеки особистості. Відповідно, завдання вбачаються в тому, аби розкрити зміст поняття „онтологічної безпеки особистості”, 3'ясувати механізми впливу релігії на різні аспекти онтологічної безпеки.

Передумови виникнення концепції онтологічної безпеки особистості знаходимо в цілого ряду дослідників, насамперед представників психології. Як найбільш знакові можемо відзначити теорії базисної довіри Е.Еріксона, внутрішнього поля людини К.Левіна, розробку поняття „самості” Ф.Перлза. Окремо виділимо теорію первинної онтологічної впевненості Р.Лейнга, що $є$ дотичною до об' єкта нашого дослідження. Однак, найбільш повно та систематизовано концепція онтологічної безпеки особистості є розкритою в працях знаного британського соціолога Е.Гідденса - автора теорії структурації.

Здійснившии спробу об'єднання герменевтики і феноменології 3 об' єктивістськими парадигмами, дослідник виділяє певне індивідуальне внутрішнє осердя, що забезпечує людині не лише відчуття захищеності, але й реального сприйняття нею навколишнього світу, що й дало змогу досліднику ввести в науковий вжиток поняття „онтологічна безпека особистості”. Останню він розуміє як „конфіденційність або довіру, які являють собою 
природний і соціальний світи, включаючи базові екзистенційні параметри самості і соціальної ідентичності" [Гидденс Э. У строение общества: очерк теории структурации. - М., 2005. - С.499].

За Е.Гідденсом, основу онтологічної безпеки становлять такі основні аспекти: по-перше, це рутинна практика соціальних дій, що пов'язана 3 ситуаціями вибору та соціальної творчості. Саме вона визначає онтологічну основу повсякденності індивіда; по-друге, це питання усвідомлення людиною скінченності свого життя; по-третє - інтерсуб'єктивність, тобто здатність відчувати інших в процесі формування соціального світу, що зрештою й робить можливим його існування; по-четверте - становлення самоідентичності, яку Е.Гідденс визначає як „постійне почуття безперервної духовної і тілесної особистості”, а також формування безпечного сприйняття світу через довіру до нього [Див.: Климов И.А. Социологическая концепція Э. Гидденса//Социологический журнал. - 2000. - № 1-2].

Перелічені чинники можемо умовно розділити на дві категорії, взявши за критерій поділу їх спрямованість. В такий спосіб виокремлюємо соціальний чинник, що включає в себе діяльність індивіда та орієнтацію на інших, і особистісний - самоідентичність та подолання „екзистенційного жаху" як основну перепону до стану захищеності.

В теорії структурації соціальний світ розглядається без зазначення первинності або ж вторинності його стосовно індивіда. Е.Гідденс акцентує увагу на пов'язаність навколишнього зовнішнього та особистісного внутрішнього. Причому, особливе місце при конструюванні та збереженні даних ареалів відводиться саме онтологічній безпеці особистості, а також станів, що нею забезпечуються.

Гідденсівський суб'єкт діяльності - агент (термін, що відповідає англійськомy agency - дія, діяльність) через інтенцію та свідомість творить соціальний світ. Інтенційність є рутинною, що й забезпечує як можливість ії, так i функціонування соціальних практик загалом. Рутинність практик досягається відтворенням їх та включенням у зовнішній світ. Агенту життєво необхідно адекватно сприймати навколишнє та усвідомлювати своє місце в ньому. Це досягається через безперервну оцінку загроз та ризиків, що й здійснюється завдяки почуттю онтологічної безпеки особистості. Вона, реально сприймаючи виклики буття, розподіляючи їх за рівнем загрози, відкидає несуттєві, дозволяє, переборюючи „екзистенційний жах”, втримувати власне „Я” в цілісності. В даному випадку забезпечується розуміння себе як соціальної істоти, збереження до певних меж самості, відчуття реальності навколишнього світу, регульована комунікація 3 „,іншими”, а також, що є надзвичайно важливим, позбавлення страху та бачення перспектив існування.

3 наведеного не важко переконатися, що онтологічна безпека особистості впритул наближена до проблеми релігії. Власне, майже всі визначення релігії тією чи іншою мірою стосуються означених станів особистості. Навіть, якщо ми звернемось до класичного марксівського 
розуміння релігії, то побачимо, що в ньому в імпліцитному і наявному виді міститься та проблематика, над якою сьогодні працюють соціологи, розв'язуючи проблему онтологічної безпеки особистості. Ф. Енгельс стверджував, що релігія $\epsilon$,фантастичним відображенням у головах людей тих зовнішніх сил, які панують над ними в їх повсякденному житті, відображенням, в якому земні сили набувають форму неземних".

Опустивши питання про фантастичну форму відображення, яке для соціолога не є суттєвим, бачимо, що йдеться про повсякденне життя, а відтак і рутинізацію практик й про страх перед непідвладними зовнішніми силами, тобто про потребу безпечного життя. Тому в контексті нашої теми наведене визначення можна викласти так: релігія $є$ одним із способів пошуку людиною своєї безпеки перед загрозою зовнішніх сил. Звичайно, слід пам'ятати, що роль релігії, як чинника онтологічної безпеки особи, $\epsilon$ досить суперечливою.

В контексті вищевикладеного актуальним є розгляд релігії сучасним українським дослідником А.М. Колодним, а саме розуміння іiі як засобу самовизначення, освоєння людиною своє причетності до Всесвітніх процесів, зведення їх воєдино через переживання Священного, усвідомлення наявності в собі містичного джерела, що спрямовує життя індивіда [Колодний А.М. Релігія //Релігієзнавчий словник. - К., 1996. - С.279-280].

Перш ніж перейти до розгляду ролі релігії в забезпеченні нею виділених нами вище аспектів онтологічної безпеки особи, варто прийняти одне із соціологічних визначень релігії, усвідомлюючи при цьому його обмеженість та необхідність звернення до інших дефініцій. Зокрема, на думку I. Яблокова, релігія виявляє себе як: 1) конкретний аспект життєдіяльності людини і суспільства, активно діючий компонент, що 3 необхідністю виникає в процесі антропосоціогенезу; 2) засіб зовнішнього вираження та механізм подолання іманентного людині відчуження; 3) спосіб відображення дійсності; 4) структурна підсистема суспільства, соціальний інститут; 5) феномен культури [История религии. В 2-х т. -Т.1. - М., 2002. С.17-28]. Для цілей нашого дослідження „працюючими” є передусім перші дві „іпостасі” релігії, що умовно можуть бути виділені в соціальний та інтерсуб' єктивний аспекти релігії.

Соціальна складова релігії, насамперед, виявляється в емоційному забарвлені дій та діяльності індивіда. Людині як мислячій істоті, наділеній свідомістю, властива духовність. Саме тому, відшукуючи опори власного буття, ми - свідомо або ж ні - вибудовуємо власне духовне творення. Чи то через створення „власної” релігії, чи пристання до певної церковної конфесії, засвоюється релігійно-духовна система, що загалом є однією з найсуттєвіших ознак людського способу діяльності та існування. Виражаючи ставлення до надприродних сил, відчуваючи їх вплив, агент, саме як суб'єкт діяльності, практично або ж дискурсивно наповнюе кожну свою дію змістом та намірами. Оскільки питання про свідомий або ж несвідомий характер такого наповнення для віруючого не є суттєвим, діяльність розглядається лише в 
контексті іï впливу на забезпечення власного сьогоднішнього (меншою мірою) та майбутнього пї буття.

Діяльність $є$ стабільною та постійною лише за умови розуміння індивідом причин такої діяльності. Релігія надає віруючому надзвичайно вагомі підстави для щоденної діяльності. Класичні дослідження на цю тему М.Вебера, порівняльний аналіз ним вірувань Сходу та Заходу доводять звернення до активної цілеспрямованої діяльності, що розв'язує буттєві питання, забезпечує активну соціальну позицію і при цьому є „освяченою” через раціональну релігію, надає впевненість у майбутньому та прихисток як для душі, так і тіла [Гараджа В.И. Социология религии. - М.,2007. - С.42-48]. Якою б не була діяльність вірного, щоденне відтворення іi, збереження рутинного характеру, подолання труднощів, пов'язаних з нею, сприймаються як надіслані Богом і $є$ важливим випробуванням на шляху до вічності.

Гідденсівське тлумачення діяльності фактично тотожне веберівському. Нагадаємо, діяльність, згідно М.Веберу, є певним видом взаємодії індивіда 3 навколишнім світом, що повинна відповідати основним вимогам. Насамперед, суб’єкт діяльності має усвідомлювати себе і мету, а також дана діяльність повинна бути направлена на зовнішнє соціальне середовище. Таким чином, як бачимо, мова йде про ті ж самі аспекти, що зазначались нами вище, а саме - соціальний та інтерсуб’ єктивний.

Подібний дуалізм простежується протягом усієї теорії Е.Гідденса. Притаманна релігії дуалістичність, яка виражається в розумінні іiі як сукупності релігійного світогляду та релігійних почуттів, як інтерсуб' єктивних чинників, з одного боку, та сукупності культових дій як чинника соціального, з іншого. Однак варто нагадати, що даний поділ $є$ суто умоглядним, оскільки навіть на перший погляд помітним $є$ зв'язок, наприклад, релігійності як внутрішньо-особистісного почуття із зовнішнім середовищем. Адже образ, а разом із ним сприйняття соціального світу, приходить через внутрішне споглядання та розуміння. Разом 3 тим, незаперечним видається той факт, що зовнішня діяльність, у нашому конкретному випадку - система релігійних дій, формує та зміцнює релігійний світогляд, адже саме це і $є$ однією з функцій релігійної діяльності.

Традиційне марксівське розуміння релігії, відкидаючи його радикально-негативний характер, не втратило актуальності й сьогодні. Адже слід розуміти, що релігія як одна 3 форм світосприйняття або ж вид суспільної свідомості, формуючись у конкретному суспільстві, не могла не перейняти та спроектувати на себе панівні суспільні відносини. За К.Марксом, основною функцією релігії $\epsilon$ ідеологічна. Вона полягає у виправданні нею існуючого несправедливого соціального ладу, віддзеркаленням у свідомості людей, іллюзією якого і є релігія. Однак, повна відмова від релігії на даному етапі розвитку людства видається неможливою, допоки не відбудеться революційна зміна соціального стану. Мислитель, називаючи ії в добре відомому вислові „неправдивою іллюзією неправдивого світу...,серцем безсердечного світу”, власне наголошує на необхідності цієї 
іллюзії, допоки потреба в ній не зникне сама собою. Людині не буде потрібен Бог, коли вона сама виховає в собі Надлюдину, скинувши кайдани відчуження й класового пригнічення - ось типове розуміння даного процесу мислителем. „В релігії міститься „людська основа”, людська дійсність, що виражається як „божествене”, у відчуженій від самої людини формі, перетворена в фантастичну дійсність" [Гараджа В.И. Социология религии. C. 41].

В такий спосіб ми виявляємо певний зв'язок даних ідей 3 досліджуваним явищем онтологічної безпеки особистості. Володіючи характером „прихистку” індивіда, який заспокоює його, нехай навіть ілюзорно, від загроз зовнішнього світу, онтологічна безпека виступає чимось на кшталт марксівського „серця світу”. Дане поняття, також надаючи відчуття усталеного порядку речей, спокою, присипляючи свідомість, заспокоює людину, що в К.Маркса викликає лише гостру критику та роздратування. Саме „божествене” виправдання суспільного ладу змушує людину змиритися з ним, що й забезпечує одну з умов існування цілісного, нехай по-марксівськи й несправедливого, суспільства, що врешті-решт також $\epsilon$ чинником забезпечення онтологічної безпеки. Для К.Маркса, який розглядав лише революцію з їі кризами і розрухою як рушій прогресу, заспокоєння, що несе релігія є зло, однак для пересічного представника суспільства, нехай і пригнобленого, який володіє мінімумом соціальних благ, надія на „Царство Боже” є дійсно єдиним прихистком від негараздів життя. I хоч для К.Маркса цей прихисток ілюзорний і не вартий уваги, для даного гіпотетичного індивіда він $є$ реальнішим за оточуючу матеріальну реальність та, власне, й таким, що надає їй реальності, а 3 нею і сенсу життя, яким би важким та злиденним воно не було б.

Загалом, звернення до суб’єктивних моментів впливу релігії на внутрішній світ індивіда допомагає краще розуміти характер зовнішньої діяльності. В соціологічній концепції виникнення релігії, що іiї запропонував Б.Малиновський, увага звертається саме на такі аспекти. Дослідник, аналізуючи функції релігії, виділяє наступні: творення релігією сенсу життя; створення відчуття психологічного комфорту та безпеки; посвята індивіда в повноправні члени суспільства через механізми ініціації; відновлення єдності групи в кризових ситуаціях [Веремчук В.И. Социология религии. - С. 9].

Як бачимо, розуміння релігії Б.Малиновським є прямо пов'язаним 3 досліджуваною нами онтологічною безпекою особистості, а саме $з$ такими іiі властивостями, як: забезпечення захищеності перед невідворотністю існування, убезпечення від зовнішніх загроз та солідарність з суспільством. „,...Звичайному індивіду релігія прагматично необхідна для того, щоб подолати гнітюче, паралізуюче передчуття смерті, нещастя і долю" [Социология: энциклопедия. (Сост. А. Грицанов и др.- Мн., 2003].

Можемо виокремити два основні типи переживання індивідом життєвих криз та негараздів. По-перше, щоденні ризики та повсякденні страхи, які невід'ємно притаманні людському життю, за сучасних умов, в 
силу розвитку технічного прогресу, набуваючі небаченого масштабу. Подруге, кризи, що стосуються довготривалих перспектив, майбутнього індивіда, при чому вони можуть торкатися як особистого життя, так і інших.

В обох наведених випадках почуття онтологічної безпеки відіграє ключову роль. Паралізуюче відчуття страху, відчаю, власної безсилості, які, перефразовуючи Ж.П.Сартра, називаємо «екзистенційним жахом», вимагають від людини надзвичайної сили духу саме для подолання їх, примирення та навіть самої можливості продовження життя. Відчуття абсурдності буття, так вдало описане філософом-екзистенціалістом А.Камю у «Міфі про Сізіфа», яскраво відображає ситуацію, коли доведена до відчаю людина здійснює крок, що позбавляє її існування.

Аналізуючи останній день цього уявного самогубці, ми можемо навіть не помітити тих елементів, що підштовхнули його до такого вчинку. Однак відповідь на питання про причини відходу від життя буде досить простою людина не змогла витримати тягар буття із всіма його негараздами, страхами, що прямо або опосередковано стосуються кожного 3 нас. Саме стійке почуття онтологічної безпеки здатне забезпечити відчуття, умовно кажучи, грунту під ногами, дозволяє долати виклики зовнішнього світу саме через примирення 3 невідворотністю його. Чи здійснює свій внесок у цей процес релігія? Безперечно. Починаючи від догматичних тверджень про самогубство як один 3 найважчих гріхів, а також через саме ставлення до смерті як невід'ємної частини життя, частини навіть притаманної йому, кожна релігія розглядає «нинішнє» лише як попередній етап. Звичайно, цей етап є важливим, засадничим, однак лише тимчасовим, таким, який передує наступному вічному життю, яке не закінчиться ніколи та, за певних обставин, буде позбавлене недоліків земного.

Розглянута нами ситуація $є$ ідеальною саме 3 позицій ставлення до релігії. Навряд чи можна назвати віруючим, у канонічному сенсі цього слова, пересічного члена суспільства. Характерні риси сучасного соціуму, які, звичайно, не можуть не впливати на соціальний інститут релігії, витворили новий тип віруючого.

Віртуальна віра $є$ тією основою, на якій грунтується ставлення до релігії сучасного індивіда. Йому притаманні, насамперед, сприйняття релігії як медійного витвору, який забезпечує задоволення духовних потреб, а також злиття мирського та духовного. Прояви такої сучасної релігійності помітні скрізь. Це і плакати на вулиці, що цитують Писання, і реклами церков на телебаченні, і телетрансляції відвідувань державними діячами богослужінь, проповіді, більше схожі на шоу. Не зважаючи на певну недолугість, така релігійність все ж забезпечує функціонування онтологічної безпеки. Людина, звертаючись до Бога, нехай навіть дома або ж у метро, не цікавиться питаннями богословського або ж теологічного характеру. Власне, їй все рівно, скільки відбулося Вселенських Соборів і на якому з них було проголошено Символ Віри. Такий пересічний сучасний віруючий звертається до Бога, рекламу якого бачив у газеті, звертається з проблемами, наприклад, 
суто економічного характеру i, відчуваючи певне заспокоєння, продовжує життя. В цьому випадку, мова не йде про бажання і максимальні зусилля бути почутим Богом, а лише про відтворення звичної практики - молитви, хресного знамення або ж інших ритуальних дій.

Чи можна критикувати таку релігійність, такий сучасний образ релігії? Звичайно, Церква відчуває занепокоєння подібним станом речей, що дозволяє їй говорити про секулярні тенденції в суспільстві. Однак, звертаючи увагу на кількість існуючих храмів, відкриття нових або ж на кількість осіб, які їх відвідують (нехай навіть і на Пасху), ми можемо стверджувати: ситуація неоднозначна.

Релігійне поняття теодіцеї відповідає на всі буттєві питання віруючого. Негаразди, лиха, життєві труднощі, будьякі соціальні проблеми сприймаються 3 позицій випробування. Оскільки земне життя $є$ лише випробуванням перед вічним щастям, то чи варто переживати через труднощі? Ось типовий приклад міркування релігійної особи. 3 таких позицій, поняття „екзистенційного жаху” долається щоденним служінням Богу. Віруючому жодні життєві обставини, як би погано вони не складались, не можуть зашкодити в осягненні головної мети його земного життя коритися Богу та любити його. Саме ці переконання в спробах стати людиною, гідною Царства Божого, наповнюють буденність змістом. Відповідно, питання про сенс життя автоматично зникає через християнську відповідь на нього [Гудінь Д, Леннокс Дж. Людина та їі світогляд: для чого ми живемо і яке наше місце у світі. - К., . - Т.1. - С.410].

Існуючи серед людей, людина все ж залишається самотньою, існує наодинці сама 3 собою. Не можна оцінювати позитиви або ж негативи цього явища, однак воно $є$ природно притаманним. Приходячи в цей світ, покидаючи його, вирішуючи проблеми та негаразди, приймаючи рішення, власне, живучи, ми залишаємось віддаленими від інших. Екзистенційна самотність є невід'ємним елементом буття. Однак, соціальна природа людської істоти вимагає відчуття єдиного соціального начала, певного осердя, яке, з одного боку, не чіпає самості індивіда, а з іншого - дозволяє злитися 3 іншими. Дана дуальність прямо стосується онтологічної безпеки особистості, що одним із критеріїв свого існування передбачає самоусвідомлення та збереження цілісного «Я» індивідом, а іншим усвідомлення соціального світу та осіб, що існують у ньому.

Чи можливе поєднання таких суб' єктивного та об'єктивного елементів життя? Жодна з структур соціального світу, поглинаючи людину, не залишає в спокої їі «Я». Саме це й викликає як девіантну поведінку, латентні форми якої притаманні майже всім, так і явну маргіналізацію як активний супротив пригніченню. Дане явище має назву «Двуликого Януса» на честь римського бога, що, як відомо, мав два обличчя. Виникає так званий когнітивний дисонанс: індивід не може без суспільства та його уособлень - соціальних структур, але індивід також не може дозволити собі (принаймні без супротиву) розчинитись у даних структурах. Чи існує розв'язання такої 
ситуації? Частково вона долається станом онтологічної безпеки, що передбачає довіру сприйняття зовнішніх структур, не звертаючи уваги при цьому на загрозу втрати самоідентичності. Однак, як зазначалося вище, онтологічна безпека особистості сама потребує розв'язання даного протиріччя між зовнішнім і внутрішнім. На роль чинника подолання такого антагонізму як найкраще підходить релігія.

Релігія, як спільний соціальний простір, $є$ унікальним випадком збереження самоідентичності та розчинення в інших. Християнське поняття «миряни» найкраще характеризує дану ситуацію. Мир сприймається як загальне, що однак, повністю підтримує особисте. Церква не може існувати без мирян, без громади, об'єднаних спільною вірою. Однак у даному об'єднанні місце знаходиться кожному, хто забажає приєднатися. Таким чином, релігійна спільнота являє собою локальну єдність, що самоідентифікує індивіда. Характерною ознакою іiї $є$ те, що дана спільнота фактично не є зафіксованою певними територіальними, культурними або расовими межами (за деякими винятками), що дозволяє долучатись до неї. Власне, таке долучення й ставиться за мету діяльності соціально легітимізованими релігійними структурами [Див.: Кондратик Л.Й. У країнське релігієзнавство доби національного відродження. - С.170-171].

Оцінка самого себе, збереження самості, самоідентифікація індивіда розглядаються з позицій об'єкта творчості Бога. Цілісність душі, як носія іскри подібності до Вищої сили, змушує докладати максимуму зусиль для збереження іiі. Розуміння людиною себе як створеної „за образом і подобою..." призводить не лише до прагнень залишатись такою як $\epsilon$, але й до певного саморозвитку. Звичайно, точкою максимуму кожної релігії $є$ стан розчинення власного „Я” у Вищому, однак незважаючи на певну парадоксальність, для досягнення такого стану необхідна максимальна внутрішня зібраність. Варто згадати лише медитативні практики, що в тих чи інших формах присутні в кожній релігії. Церква, як структура, в яку включена віруючалюдина, вимагає повної участі в собі.

Але чи можна поєднувати впливи іiі 3 впливами суто соціальних структур? Для стороннього спостерігача діяльність церкви з поглинення самості, $є$ не менш деструктивною. Однак для самого віруючого даний вплив не є відчутним, залишаючи однак відчуття єднання з об' єктом віри, що, як зазначалося вище, вимагає внутрішньої структурованості та цілісності. Таким чином, церковність, поглинаючи „Я”, призводить до його переродження в інших. Насамперед, це відбувається тому, що індивід, невідчуваючи внутрішнього супротиву, з готовністю включається в структуру, формуючи духовний егрегор.

Традиційне звертання християн одне до одного, що вказує на родинну спорідненість, $\epsilon$, мабуть, найкращим підтвердженням впливу релігії на ставлення до інших. У явлення про Бога як єдиного Отця, а відтак сприйняття всіх, хто вірить у нього, як своїх духовних братів та сестер, призводить до гармонізації стосунків та зведення конфліктів до мінімуму. Відбувається 
ситуація, яку Г.Зіммель образно назвав картиною світу, що для всіх вірних $\epsilon$ намальованою одними кольорами та сприймається в одному кольоровому спектрі [Зиммель Г. Релігія. - С.562]. Дана ситуація, звичайно, є ідеальною. Однак сьогодні ми $є$ очевидцями подій, за яких належність до певної віри або ж конфесії стає певним новітнім тотемом. Маються при цьому на увазі заклики „Ми християни, а отже брати...”, „Ми українці, бо ми православні...”. Навіть несприйняття релігійного радикалізму, націоналізму, звернення лише до розуміння всіх людей як рівних одне одному, яке декларується більшістю релігій, здатне, без сумніву, забезпечувати відчуття інших в собі самому, що володіє зворотнім характером.

Таким чином, можемо підсумувати, що загалом релігія як складне комплексне явище цілком забезпечує функціонування кожного 3 аспектів онтологічної безпеки особистості, при цьому гармонійно поєднуючи та інтегруючи їх. Буттєва рефлексивність індивіда, до якої призводять одвічні питання первинності ідеального та матеріального, знаходить своє розв'язання через образ Бога. Віруюча людина не переймається «надмірними» запитаннями. У свідомлення нею себе, по-перше, як проміжної ланки між природним світом та Богом, а, по-друге, як носія «частинки» Бога в собі, гармонійно виливається в певний образ світу як Його витвір. Образ, що $є$ позбавленим духовного та матеріального антагонізмів, саме через свій уявний, ідеальний характер, однак для суб' єкта сприйняття цілком реально існуючий. Звичайно, мова не йде про повну ідеалізацію, а лише про ставлення та сприйняття, які, власне, й формують бачення.

Отже, виникає закономірне питання: чи не $є$ поняття релігії та онтологічної безпеки особистості за своєю суттю тотожними, такими, що лише по різному описують один і той же самий внутрішній стан людини?

Насамперед, релігія $\epsilon$ надзвичайно широким, загальнолюдським, загальноцивілізаційним комплексом, який здійснює свій вплив як на окремого індивіда, так і цілі суспільства. Стверджувати, що релігія обмежується забезпеченням почуття захисту, впевненості, цілісності людини та на цьому іï функції припиняються, звичайно є абсолютно невірним. Ми лише розглядаємо релігію як один із чинників, що через вплив на індивіда формує почуття онтологічної безпеки, яке, на відміну від джерел свого походження, є суто соціальним, тобто стосується практичних аспектів соціального світу. В протилежність до релігії почуття онтологічної безпеки акцентує свою увагу на земному, щоденному образі людини, образі, який даною людиною твориться та підтримується, що відбувається також і завдяки релігії.

Власне, поняття релігії нами використовується досить широко, оскільки за умов сучасного суспільства, коли вона переживає якщо не постмодерний стан, то принаймні New Age, говорити про традиційну віру в Бога видається не зовсім доцільним. Тобто, варто, насамперед, релігію розглядати як комплекс віри в надприроднє, таке, що виходить за межі сприйняття людиною, а що стосується образу даного об' єкта віри, то це вже 
абсолютно інше питання, яке, за великим рахунком, для віруючого не має особливого значення.

Слід усвідомити, що описані нами впливи релігії на забезпечення функціонування елементів онтологічної безпеки особистості, $є$ загалом ідеальними. Ми не розглядаємо наявність даного почуття як обов'язкову притаманність лише віруючої людини, оскільки це було б абсолютно недопустимим. Насамперед, зазначається вплив релігії як одного з чинників, а також розуміється, що абсолютно невіруючої людини не існує. Оскільки онтологічна безпека особистості використовує лише елементи релігійного світогляду, то нею не передбачається обов' язковість віри в Бога. Важливим є звернення до надприродного, характеристики якого та загальний образ визначаються самим індивідом. Саме це й призводить до того, що особа, яка вважає себе атеїстом, обожнюючи наукове знання, зазнає впливів цієї своєрідної ,„релігії” на власному почутті онтологічної безпеки, в такий спосіб забезпечуючи його підтримку та функціонування.

Зазначимо, що можлива ситуація, за якої релігія, а точніше саме віра в Бога, заміщує собою онтологічну безпеку особистості. Цей стан $є$ досить небезпечим. У такому випадку соціальне, за великим рахунком перестає адекватно сприйматись, оскільки домінуючим для індивіда стає трансцендентне. Саме в кантівському розумінні воно призводить до поступового розчинення особистості. Таке розчинення власного „Я” не $\epsilon$ істинно релігійним, а стосується, насамперед, лише питань побуту та влаштування власного буття, образно кажучи, надлишок релігії подібний до стану іiі відсутності саме в контекстах онтологічної безпеки особистості. В цих випадках доцільним є звернення до фрейдистського тлумачення. Бог як страшний всеохоплюючий батько, що милує та карає, всесвітнє скопище неврозів - ось основні його характеристики. Однак, саме за описаних вище умов звернення до тлумачення, так званої, невротичної релігійності, дозволяє пояснити фанатичну поведінку індивіда, що загалом є асоціальною. Даний приклад безвідносно до всієї його глибини лише підкреслює відмінності проміж релігією, iї проявами та почуттям онтологічної безпеки особистості як соціального їі виміру.

Насамкінець, зазначимо, що нами було розглянуто лише один 3 аспектів дослідження онтологічної безпеки особистості, що, без сумніву, потребує докладного вивчення. Актуальність розуміння і вивчення даного почуття зростає з кожним днем. Бачення релігії як фактору підтримки в людині цілісності, адекватного сприйняття зовнішнього світу, гармонізації стосунків 3 оточуючими, а також почуття захищеності і впевненості в майбутньому, є ще одним прикладом хибності розподілу духовно-ідеального і соціально-наукового, що є нині популярним. „Віра і розум подібні до двох крил, на котрих дух людський піднімається до споглядання істини" - мабуть, такі слова Івана Павла II найкраще свідчать про це. 